\author{
Angelika Kędzierska-Szczepaniak (iD https://orcid.org/0000-0001-6760-7809 \\ Uniwersytet Gdański \\ e-mail: a.szczepaniak@ug.edu.pl
}

\title{
The Crowd Wisdom in Financing Cultural Projects
}

Abstract

Culture is an important determinant in assessing the development and growth of the individual economies and societies. The culture sector is financed from public and private (patrons of art, sponsors) sources. However the funds for this sector are not enough to cover all the needs. Finding new possibilities of funding culture becomes particularly important. One of the possibilities is to encourage the society to co-finance cultural initiatives that are important and valuable for them. This kind of crowd wisdom can be implemented through crowdfunding. Crowdfunding has enabled large crowds to fund innovative cultural projects. This type of support might tap into the wisdom of crowds who were previously disconnected from the funding process. The aim of this article is to analyze the idea of crowdfunding in the cultural projects. Some successful examples of crowd wisdom in financing cultural projects in Europe are discussed in the article.

Keywords: crowdfunding, social funding, cultural projects financing, crowd wisdom, reward-based crowdfunding.

Słowa kluczowe: finansowanie społecznościowe, finansowanie społeczne, finansowanie kultury, mądrość tłumu, crowdfunding oparty na nagrodach.

\section{Introduction}

Culture and cultural projects are important for the development of societies. However, culture expenditure is insufficient almost everywhere. Government expenditure on recreation, culture and religion in EU countries fluctuate around 1\% of gross domestic product (GDP). Due to this fact, cultural organizations have to seek other alternative forms of funding. One of the forms which are more and more popular 
after the financial crisis, is crowdfunding. It is an internet-enabled way to raise money from multiple individuals. Crowdfunding can be an opportunity to implement many cultural initiatives by means of using crowd wisdom. People, as the crowd, decide what kind of initiatives they want to support. The gathering is organized on professional crowdfunding platforms. There are examples of crowdfunding platforms that are dedicated directly to cultural projects. The people who want to participate in culture supporting can do it on a large scale (e.g. Louvre) but also in smaller local initiatives.

The aim of this article is to analyze the idea of crowdfunding in cultural projects. Examples of crowd wisdom in financing cultural projects in Europe will be presented including two examples of Polish crowdfunding platforms that support cultural initiatives given at the end. The data used in this article comes from the European Commission, the Polish Ministry of Finance and crowdfunding platforms supporting culture.

\section{Literature review}

The financing of cultural project is an important research area around the world. Funding for culture can come from various sources. The importance of market economy in financing culture was noticed by Ilczuk and Misiąg [2003]. A wide spectrum of financing possibilities for culture was presented by Głowacki et al. [2008]. Detailed information on the availability of various sources of financing for cultural institutions was presented by Borowiecki [2005] and Barański [2015]. Ilczuk mentioned five basic models of public authorities policy with regard to culture [2012]. Inspirational examples regarding financing culture from public funds can also be found throughout the European Union [Financing the Arts and Culture in the European Union 2006], as well as in selected countries [Stano-Strzałkowska 2017]. The problem of culture financing in the EU countries was analyzed by the researchers from Bucharest [Manda, Nicolescu, Mortelmans 2017]. The Central Statistical Office of Poland publishes information about culture financing in Poland as well [Chochorowska et al. 2016]. All the research topics concern traditional forms of financing. The main problem for culture financing is that those sources are insufficient. Therefore, alternative forms of financing cultural initiatives should be sought. The method which is increasingly important in culture financing is crowdfunding. Crowdfunding is one of the four main types of crowdsourcing which also plays an important role in cultural heritage [Ridge 2014]. The growing role of the Internet is also important in the aspect of crowdsourcing and crowdfunding development [Kowalska 2015]. The description of the idea of crowdfunding was offered by Dresner [2014]. It is the practice of funding an initiative by raising money from a large number of people via the Internet. The first country that allowed the 
development of crowdfunding was the United States of America [Kappel 2009] but it soon came to Europe as well [Brüntje, Gajda 2016]. The USA was also the first country which introduced changes to law because of crowdfunding [Cunningham 2012]. Crowdfunding started to develop because of the financial crisis in 2008 which caused financial damage both to individuals and businesses. Traditional forms of financing were always difficult to obtain for small and medium enterprises but it became nearly impossible after the financial crisis. Credit institutions and banks refused to lend money even to profitable and successful businesses. Paradoxically, the financial crisis was a chance as well - for the alternative forms of financing both from within the existing financial sector and through newcomers. One of the biggest and best known crowdfunding platforms Kickstarter was launched in 2009, shortly after the crisis began [https://www.kickstarter.com 2018]. This platform was created because the owner (who was a musician) wanted to help artists and musicians to raise money for their initiatives. The researchers noticed that the wisdom of crowds in financing plays important role [Polzin, Toxopeus and Stam 2018]. Various models of crowdfunding appeared along with the development of crowdfunding. The majority of funds raised via crowdfunding platforms focus on the four main models - donation, reward-, equity- and lending-based [Belleflamme, Lambert, Schwienbacher 2013]. A number of scientific papers have since emerged including descriptive approach and case studies [Ingram, Teigland, Vaast 2014; Tomczak, Brem 2013]. The perspectives of crowdfunding development on the Polish market were presented by Pluszyńska and Szopa [2018] and Kędzierska-Szczepaniak, Szopik-Depczyńska and Łazorko [2016]. The subject of cultural support has already been analyzed in the Polish market as well. The example of music financing was described by Gałuszka and Bystrov [2013]. They also presented the barriers related to crowdfunding platforms activity [Gałuszka, Bystrov 2012]. The role of crowdfunding for the film production on the Polish market was described in 2016 [Świerczyńska-Kaczor and Kossecki]. The analysis of cultural projects supported by crowdfunding on the EU market was made by Kędzierska-Szczepaniak and Próchniak [2018].

\section{The support for culture in EU countries}

Culture is an area of the economy which includes the creation and distribution of goods containing both material and spiritual (cultural) values. This culture can be divided into non-industrial and industrial sectors. The non-industrial sector produces non-productive goods and services and includes performative and visual arts and heritage. The industrial sector manufactures goods and services, e.g. films and audiovisual production, video games, television, book and press publications [Borowiecki 2005]. 
Currently, the culture sector often shares and cooperates with the creative sector. The cultural and creative sectors refer to those parts of the modern innovative economy where culture is produced and distributed through industrial means. The cultural and creative sectors bring together the arts, media, and design sectors, with a focus upon convergent digital technologies and the challenges and opportunities of globalization [Flew 2017].

The cultural and creative sectors (CCS) play a crucial role in driving social and economic development of the European Union. It brings people and societies together and helps to build strong international relations. The European Commission announced in May 2018 that for the next EU budget 2021-2027 they propose increasing funds for Creative Europe [European Commission 2018]. It is needful because the digital environment develops quickly and transforms the cultural landscape. It brings new challenges and opportunities to culture and creative sector, but on the other hand it needs more funds. The program proposed by the European Commission concentrates on three areas: media (EUR 1,081 billion), culture (EUR 609 million) and across cultural and media sectors (EUR 160 million) (EC 2018). The first one will support the distribution, development and promotion of European TV programs, films and video games. The second program will promote European cultural and creative sectors. Some cooperation projects will be arranged to connect artists from EU countries. The last one will support organizations and small and medium-sized enterprises working in the cultural and creative sectors. The information about additional support for the CSS is good but one should be aware that the funds for culture do not concern performances, films, movies or concerts only. Cultural expenses are often associated with very expensive maintenance of local, national or even world heritage sites.

Despite the nominally increasing funds allocated for financing culture and national heritage, many cultural projects do not receive co-financing. Considering the fact that the needs are growing and are not accompanied by a sufficient increase in budget expenditures on culture, other solutions have been sought that could help solve financial problems.

The average expenditure on recreation, culture and religion for the European Union measured as a percentage of GDP is around $1 \%$ (the highest is 1,2\% in 2009). The four countries that have the highest expenditures on CCS measured as a percentage of GDP are Hungary, Estonia, Denmark and Croatia in 2016. The situation is a little bit better when the total expenditures on recreation, culture and religion are measured as a percentage of total government expenditures. The average for EU countries is $2,2 \%$ then. 
Table 1. Total general government expenditures on recreation, culture and religion in EU countries in 2015 and 2016

\begin{tabular}{|c|c|c|c|c|c|c|c|c|}
\hline GEO/UNIT & 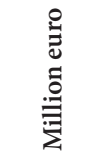 & 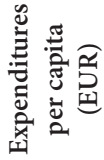 & 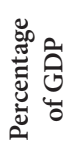 & 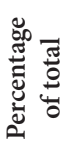 & 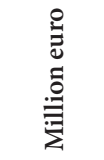 & 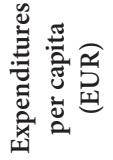 & 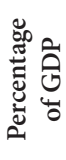 & 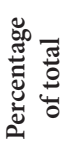 \\
\hline & \multicolumn{4}{|c|}{2015} & \multicolumn{4}{|c|}{2016} \\
\hline Hungary & 2356,0 & 239,1 & 2,1 & 4,2 & 3769,4 & 383,4 & 3,3 & 7,1 \\
\hline Iceland & 487,5 & 1481,3 & 3,2 & 7,5 & 554,5 & 1667,5 & 3,0 & 6,7 \\
\hline Estonia & 398,3 & 302,9 & 2,0 & 4,9 & 432,9 & 329,0 & 2,1 & 5,1 \\
\hline Denmark & 4804,2 & 848,8 & 1,8 & 3,2 & 4895,2 & 857,7 & 1,8 & 3,3 \\
\hline Croatia & 711,9 & 168,5 & 1,6 & 3,4 & 822,0 & 196,2 & 1,8 & 3,8 \\
\hline Norway & 5142,5 & 995,4 & 1,5 & 3,0 & 5320,1 & 1021,0 & 1,6 & 3,1 \\
\hline Latvia & 393,3 & 198,0 & 1,6 & 4,2 & 360,9 & 183,3 & 1,4 & 3,9 \\
\hline Slovenia & 632,5 & 306,6 & 1,6 & 3,4 & 576,8 & 279,4 & 1,4 & 3,2 \\
\hline Finland & 3106,0 & 567,6 & 1,5 & 2,6 & 3112,0 & 567,1 & 1,4 & 2,6 \\
\hline Czech Republic & 2242,2 & 212,8 & 1,3 & 3,2 & 2283,1 & 216,3 & 1,3 & 3,3 \\
\hline Netherlands & 9575,0 & 566,5 & 1,4 & 3,1 & 9431,0 & 555,4 & 1,3 & 3,1 \\
\hline Belgium & 4965,6 & 441,9 & 1,2 & 2,2 & 5249,6 & 464,1 & 1,2 & 2,3 \\
\hline France & 28515,0 & 429,1 & 1,3 & 2,3 & 27753,0 & 415,9 & 1,2 & 2,2 \\
\hline Luxembourg & 590,7 & 1049,3 & 1,1 & 2,7 & 653,9 & 1134,8 & 1,2 & 2,9 \\
\hline Austria & 4157,6 & 484,3 & 1,2 & 2,4 & 4258,4 & 489,4 & 1,2 & 2,4 \\
\hline Spain & 12593,0 & 271,1 & 1,2 & 2,7 & 12383,0 & 266,6 & 1,1 & 2,6 \\
\hline Poland & 4844,2 & 127,5 & 1,1 & 2,7 & 4532,2 & 119,4 & 1,1 & 2,6 \\
\hline Sweden & 4892,9 & 502,0 & 1,1 & 2,2 & 5080,5 & 515,7 & 1,1 & 2,2 \\
\hline Bulgaria & 766,3 & 106,4 & 1,7 & 4,2 & 469,8 & 65,7 & 1,0 & 2,8 \\
\hline Germany & 30571,0 & 376,5 & 1,0 & 2,3 & 31691,0 & 385,6 & 1,0 & 2,3 \\
\hline Lithuania & 351,7 & 120,4 & 0,9 & 2,7 & 393,2 & 136,1 & 1,0 & 3,0 \\
\hline Malta & 112,2 & 255,2 & 1,2 & 2,9 & 98,9 & 219,6 & 1,0 & 2,6 \\
\hline Slovakia & 810,3 & 149,5 & 1,0 & 2,3 & 792,9 & 146,1 & 1,0 & 2,4 \\
\hline Cyprus & 161,0 & 190,1 & 0,9 & 2,2 & 162,5 & 191,6 & 0,9 & 2,3 \\
\hline
\end{tabular}




\begin{tabular}{|c|c|c|c|c|c|c|c|c|}
\hline GEO/UNIT & 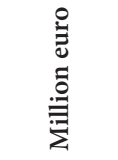 & 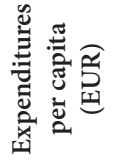 & 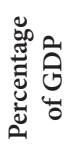 & 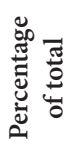 & 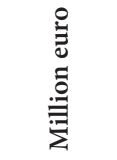 & 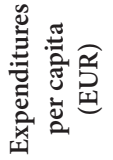 & 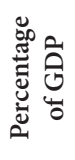 & 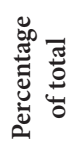 \\
\hline & \multicolumn{4}{|c|}{2015} & \multicolumn{4}{|c|}{2016} \\
\hline Romania & 1600,5 & 80,5 & 1,0 & 2,8 & 1564,2 & 79,2 & 0,9 & 2,7 \\
\hline Greece & 1217,0 & 112,1 & 0,7 & 1,3 & 1329,0 & 123,2 & 0,8 & 1,5 \\
\hline Italy & 12563,0 & 206,6 & 0,8 & 1,5 & 14254,0 & 235,0 & 0,8 & 1,7 \\
\hline Portugal & 1485,0 & 143,1 & 0,8 & 1,7 & 1513,2 & 146,3 & 0,8 & 1,8 \\
\hline Switzerland & 5017,2 & 609,1 & 0,8 & 2,4 & 5013,2 & 602,0 & 0,8 & 2,4 \\
\hline $\begin{array}{l}\text { United King- } \\
\text { dom }\end{array}$ & 17344,0 & 267,3 & 0,7 & 1,6 & 15390,2 & 235,4 & 0,6 & 1,5 \\
\hline Ireland & 1427,0 & 305,1 & 0,5 & 1,9 & 1505,7 & 318,6 & 0,5 & 2,0 \\
\hline $\begin{array}{l}\text { European } \\
\text { Union }\end{array}$ & 153187,5 & 301,2 & 1,0 & 2,2 & 154758,6 & 303,3 & 1,0 & 2,2 \\
\hline
\end{tabular}

Source: own elaboration based on: European Commission 2018.

As it was presented in table, 1 the expenditures on culture are not sufficient. Organizations, foundations and other institutions of culture need to find other possibilities of financing cultural expenditures. The main possibilities of financing for the cultural and creative sector are presented in picture 1.

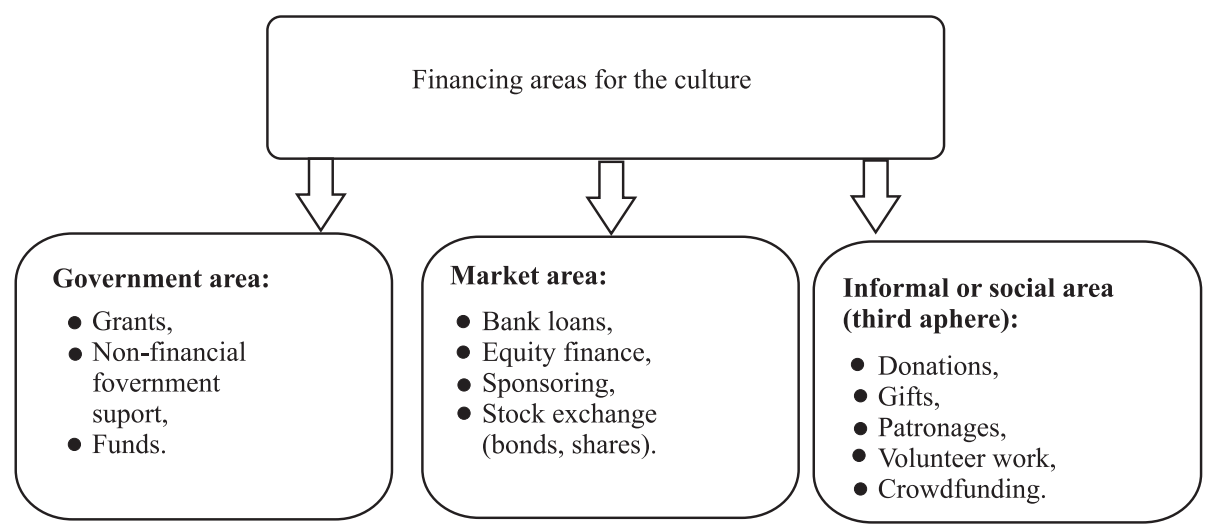

Picture 1. Areas of external finance for the cultural and creative sector Source: own elaboration based on Klamer 2005. 
Many traditional financial institutions, creditors and banks do not accept the risks associated with cultural and creative projects, and such activities do not receive financing. Crowdfunding appears as an interesting alternative not only for the CCS but for the culture general because of the financial crisis and the insufficient public expenditures on culture.

\section{The role of crowdfunding in supporting cultural projects in Europe}

The society and its willingness can play an important role in financing culture and in supporting specific cultural initiatives. The wisdom of the crowd in the general sense of the word is based on the collective opinion of a group of individuals rather than a single expert. The aggregated answers to various questions have been found to be as good as, or even better than, the answer given by any of the individuals within the group. Large groups of people are better at solving problems, fostering innovation, coming to wise decisions, even predicting the future [Surowiecki 2004].

In the aspect of culture financing, the people as a groups have a great strength and are able to mobilize in the common accomplishment of goals. The definition characterizes a crowd as a group of people amassed by an open call for participation [Prpić et al. 2015]. One of the most interesting examples of crowd wisdom in culture financing was the support of American and French societies for financing the pedestal of the Statue of Liberty. The Statue of Liberty was a gift for Americans from French people. There was a problem with the fact that more money was needed for building the pedestal. Joseph Pulitzer, who was a publisher in New York, announced in 1885 on the pages of the newspaper "World" a campaign for financial contribution to the pedestal. After 5 months he received more than USD 102,000 from the citizens of New York [Harris 1986]. The crowd wisdom made the Statue of Liberty possible to stay in New York. The people decided they wanted to have this monument and they paid for it. Many researchers regard that as the first example of crowdfunding.

Crowdfunding is more visible in the 21 st century. It is possible to announce various cultural initiatives that have not received the support from the budget or this support has proved insufficient, via the Internet and social media. The crowdfunding for culture is developing in all European Countries. As it was mentioned before, there are four main models of crowdfunding: donation- and reward-based (those two are without financial return) and equity- and lending-based (with financial return). The crowdfunding without financial return is more popular for culture due to the specificity of this activity. The idea of crowdfunding is that potential projects are announced and promoted on crowdfunding platforms to raise money from the society/crowd. The crowd takes the final decision - will it support the project and the initiative will be implemented as a result or not. Some cultural organizations in 
Europe decided to use crowdfunding for its initiatives. The most famous examples, taking into account the importance of the initiative are presented in table 2.

Table 2. Examples of crowdfunding initiatives for culture in Europe

\begin{tabular}{|l|l|c|}
\hline \multicolumn{1}{|c|}{ Initiative } & \multicolumn{1}{c|}{ Country } & Year \\
\hline Three Graces & France/Louvre & 2010 \\
\hline The Treasures of Cairo & France/Louvre & 2011 \\
\hline The Book of Hours & France/Louvre & 2017 \\
\hline The Domus Centaurus in Pompei & Italy & 2015 \\
\hline The Corsini Gallery of Rome & Italy & 2015 \\
\hline
\end{tabular}

Source: own elaboration.

One of the examples of using crowd wisdom in the program called "Everyone' a Patron!" ("Tous mécenes!") in Louvre. The Louvre Museum was the most visited museum in the European Union in 2014 considering the number of admission tickets [Statistical Book Eurostat 2016]. Since 2010 the museum has been encouraging individuals and businesses, not only from Paris or France but also from all over the world to become patrons of arts. The society can make donations and as a result enrich the collections of the Louvre Museum. The program was started when the museum wanted to buy the Three Graces by Lucas Cranach. The campaign was successful. The next campaign, in 2011, concerned raising money to finance the acquisition of the Treasures of Cairo collection for EUR 2.6 million (65\% of the sum donated by the Association of the Friends of the Louvre and a French insurance company, EUR 800,000 was gathered by crowdfunding). Another crowdfunding initiative was announced in 2017 and concerned the acquisition of the Book of Hours from Great Britain. There was no barrier for the Louvre to buy this manuscript because in November 2016 when the UK export license for the Book of Hours was issued [http://presse.louvre.fr/ become-a-patronof-king-francois-is-book-of-hours/ 2018]. The campaign was closed in February 2018. The total value of funds collected from the crowd was EUR 1 million (accounting for over $160 \%$ of the set target). Half of the amount was provided by LVMH group [www.tousmecenes.fr 2018].

The next example of using crowd wisdom in culture financing is Italy. The treasures of architectural culture in Italy are falling apart due to the lack of maintenance funds. Italian culture is highly underinvested. Some monuments are closed and excluded from accessibility due to concerns about their stability. A global society project LoveItaly! was proposed in 2015. It is a nonprofit initiative started by LVenture Group which want to encourage people to make donations for Italian 
culture. The aim of this program is to restore the centrality of the cultural heritage. Two crowdfunding campaigns were initiated at the beginning of this venture: the restoration of Cubicle 3 of the Domus Centaurus in Pompei and the restoration of an extraordinary imperial sarcophagus exhibited in the Corsini Gallery of Rome [http://lventuregroup.com/loveitaly-crowdfunding-for-the-italian-culturalheritage/?lang=en 2018].

This solution with donations from the society was well received by people and the government. As a result, there is an innovative tax incentive for those who support culture with donation, called "Art bonus". It is a tax credit of $65 \%$ of charitable contributions (both for companies and individuals) made in favor of public cultural heritage [https://artbonus.gov.it/english-brief.html 2018]. The "Art bonus" also grants $30 \%$ incentives on touristic structures when they invest in renovation.

The examples of France and Italy show that individuals want to be a part of the crowd and support culture. Those initiatives are more and more popular in other EU countries. It is possible because the number of crowdfunding platforms for culture is growing from year to year. There are three main types of crowdfunding platforms (Baumgardner et al. 2015):

1) specialized platforms - focused on specific industries (e.g. music recording only);

2) activity-specific platforms - open for various industries but focus on particular types of projects (e.g. creative projects);

3) general-purpose platforms -available for wide variety of industries and individuals.

There are many platforms that are general (not dedicated to culture) but it is possible to start a culture campaign there as well. There is a risk that a cultural campaign will go unnoticed among a huge number of other initiatives. For this reason, the initiators of cultural projects often prefer specialized platforms or do it themselves (like in France and Italy). There are platforms that are specialized for cultural project in the European Union (table 3).

The research about crowdfunding in culture was made by the European Commission in 2016. It showed that cultural and creative sectors launched more than 75,000 campaigns and gathered more than EUR 247 million in Europe since 2013 [De Voldere, Zeqo 2017]. More than half of the campaigns are "Film and Audiovisual" (33\% of transactions number and $29 \%$ of transactions volume) and "Music" ( $22 \%$ of transactions number and $17 \%$ of transaction volume).

Announcing cultural initiatives on a crowdfunding platform gives the possibility of gathering funds but also creates other values, e.g. the promotion of culture, community engagement, audience development and creation of demand for cultural projects [De Voldere, Zeqo 2017]. 
Table 3. Examples of specialized crowdfunding platforms for culture and creative sectors in Europe

\begin{tabular}{|c|c|c|c|}
\hline No. & Platform & Country & Information \\
\hline 1. & $\begin{array}{l}\text { Ulule } \\
\text { https://www.ulule.com/ }\end{array}$ & France & $\begin{array}{l}\text { The platform was founded in } 2010 \text {. It helped to raise } \\
\text { funds for over } 24,665 \text { creative, innovation or civic pro- } \\
\text { jects with a } 62 \% \text { success rate. There are two options for } \\
\text { collecting money there - a project manager could put up } \\
\text { an amount needed for project implementation or arrange } \\
\text { a pre-sale of product. }\end{array}$ \\
\hline 2. & $\begin{array}{l}\text { Crowdculture } \\
\text { https://www.sics.se }\end{array}$ & Sweden & $\begin{array}{l}\text { The platform has untypical rules for collecting money. } \\
\text { The initiative can encourage the funds of both private } \\
\text { investors and state funds (from the culture budget of } \\
\text { the country). The share of state money depends on the } \\
\text { number of votes received by the project among platform } \\
\text { participants. }\end{array}$ \\
\hline 3. & $\begin{array}{l}\text { Goteo } \\
\text { https://en.goteo.org/ }\end{array}$ & Spain & $\begin{array}{l}\text { It offers a unique financing methodology carried out in } \\
\text { two rounds lasting } 40 \text { days each. The aim of the first ro- } \\
\text { und is to collect a minimum amount for initiative launch. } \\
\text { An optimal sum is collected for initiative improvement } \\
\text { during the second round. more than EUR } 7 \text { mln were } \\
\text { raised since } 2011 \text { and the success rate is } 75 \% \text {. }\end{array}$ \\
\hline 4. & $\begin{array}{l}\text { Derev } \\
\text { https://www.derev.com/ }\end{array}$ & Italy & $\begin{array}{l}\text { This is a platform for introduction of social innova- } \\
\text { tions. It gives the opportunities for collecting signatures } \\
\text { for petitions and ordering air time to broadcast state- } \\
\text { ments or interviews as well. }\end{array}$ \\
\hline 5. & $\begin{array}{l}\text { Wemakeit } \\
\text { https://wemakeit.com }\end{array}$ & Switzerland & $\begin{array}{l}\text { This is the largest platform for creative industries in } \\
\text { Switzerland. It supports non-profit organizations by } \\
\text { financing their initiatives and helping to develop their } \\
\text { communities. The total amount of backings till Septem- } \\
\text { ber } 2018 \text { was EUR } 35,7 \mathrm{~m} \text {, the success rate is } 62 \% \text {. }\end{array}$ \\
\hline 6. & $\begin{array}{l}\text { Biggggidea (Spilnokosht), } \\
\text { https://biggggidea.com/ }\end{array}$ & Ukraine & $\begin{array}{l}\text { This platform collects funds for projects in health care, } \\
\text { education, music, literature, music, research and jour- } \\
\text { nalism. }\end{array}$ \\
\hline 7. & $\begin{array}{l}\text { StudentBackr } \\
\text { https://studentbackr.com }\end{array}$ & Spain & $\begin{array}{l}\text { The platform is specialized in education and provides } \\
\text { students with a tool to collect the money they need to fi- } \\
\text { nance their college tuition, study abroad, travel costs, etc. } \\
\text { This platform operates in North America and Europe. }\end{array}$ \\
\hline 8. & $\begin{array}{l}\text { Wspieramkulture } \\
\text { wspieramkulture.pl }\end{array}$ & Poland & $\begin{array}{l}\text { It is a platform that allows creators to collect funds } \\
\text { for cultural projects. It is the first social crowdfunding } \\
\text { platform in Poland entirely dedicated to cultural proj- } \\
\text { ects. The service has been operating since December } \\
2012 \text {. }\end{array}$ \\
\hline
\end{tabular}

Source: own elaboration based on crowdfunding platform sites. 


\section{The example of crowd wisdom on the Polish market}

Like in other countries, budget expenditures are insufficient each year to meet the needs of all cultural institutions in Poland. Some actions to increase spending on culture have been undertaken for over ten years. The first program for financing the digitization of cultural goods was launched in 2007. The national program "the Culture +" was signed in 2010 for 2011-2015. The main goal of this program was to improve access to culture in local communities. One of the priorities was "Digitalization". The Digital Inheritance Program assumed financial support for initiatives that served the digitalization of cultural heritage [http://www.nina.gov.pl 2015].

The Covenant for Culture (which is also an example of crowd wisdom in cultural support) was established in 2011. The amendment to the act on organizing and conducting cultural activities was signed in 2012 [http://www.mkidn.gov.pl 2012].

Apart from state funding, institutions of culture may also receive subsidies from the budget of the local government units in Poland. Those funds are spent to cover the costs of statutory activity [Ustawa $\mathrm{z}$ dnia 25 października 1991 o organizowaniu i prowadzeniu działalności kulturalnej]. It is a subject-based subsidy. The responsibility of the local governments it to provide the necessary funds to operate the cultural institution. There is also a possibility for the local government unit to provide an appropriate subsidy for cultural institutions for the implementation of a specific investment. Local governments may grant subsidies for investment expenditures to state cultural institutions from their budgets, according to article 28 paragraph 1b [Ustawa z dnia 25 października 1991 o organizowaniu i prowadzeniu działalności kulturalnej]. However, a condition for granting such a subsidy is that the investment task for which the subsidy is granted is related to the activities of the cultural institution for which it was created.

The share in public culture financing by local governments varies from $65 \%$ to 83\% depending on year (table 4). This share is lower and lower since 2013.

The funds given by Local Governments are not sufficient to cover the costs of culture-related activities. Many projects are not implemented because the commune or city does not have enough budget. As a result, cultural organizations often have to look for other sources of financing. At the same time, the share of expenditure on culture in the expenditure of the state budget increases but total expenditures are low and insufficient - ranging from $0.23 \%$ to $0.42 \%$, depending on the year (table 5). 
Table 4. Share of Local Government Units expenditures in total public culture expenditures

\begin{tabular}{|c|c|c|}
\hline Year & $\begin{array}{c}\text { Total expenditures on culture } \\
\text { in million PLN }\end{array}$ & $\begin{array}{c}\text { Local government expenditures on culture } \\
\text { (as a \% of total expenditures) }\end{array}$ \\
\hline 2007 & 6043,6 & $78,26 \%$ \\
\hline 2008 & 6898,3 & $78,45 \%$ \\
\hline 2009 & 7947,2 & $79,96 \%$ \\
\hline 2010 & 8454,3 & $82,87 \%$ \\
\hline 2011 & 8248,3 & $81,89 \%$ \\
\hline 2012 & 8564 & $79,95 \%$ \\
\hline 2013 & 8520,6 & $80,84 \%$ \\
\hline 2014 & 9462,6 & $81,62 \%$ \\
\hline 2015 & 8887,6 & $77,89 \%$ \\
\hline 2016 & 9259,7 & $72,06 \%$ \\
\hline 2017 & 10739,9 & $68,98 \%$ \\
\hline
\end{tabular}

Source: own elaboration based on Ministry of Finance data, www.mofnet.gov.pl.

Table 5. The share of expenditures on culture in the total state budget expenditures

\begin{tabular}{|c|c|c|}
\hline Year & $\begin{array}{c}\text { State budget expenditures for culture } \\
\text { in million PLN }\end{array}$ & $\begin{array}{c}\text { Stage budget expenditures for culture } \\
\text { as \% of total state budget expenditures }\end{array}$ \\
\hline 2007 & 1313,70 & $0,27 \%$ \\
\hline 2008 & 1486,70 & $0,28 \%$ \\
\hline 2009 & 1592,80 & $0,27 \%$ \\
\hline 2010 & 1448,10 & $0,23 \%$ \\
\hline 2011 & 1493,70 & $0,23 \%$ \\
\hline 2012 & 1717,00 & $0,25 \%$ \\
\hline 2013 & 1632,80 & $0,23 \%$ \\
\hline 2014 & 1739,50 & $0,24 \%$ \\
\hline 2015 & 1964,80 & $0,27 \%$ \\
\hline 2016 & 2586,70 & $0,35 \%$ \\
\hline 2017 & 3331,90 & $0,42 \%$ \\
\hline
\end{tabular}

Source: own elaboration based on Ministry of Finance data, www.mofnet.gov.pl. 
Despite this increase, funds for culture are not enough. Entrepreneurs, sponsors and donators support cultural initiatives very often but sometimes they are not interested in funding smaller or local projects. Therefore there is also a chance for crowdfunding development in this field in Poland.

The first crowdfunding platform established in Poland was also dedicated mainly to culture (music, art and video games). It was the MegaTotal.pl music label. This portal has finalized over 113 music projects since the beginning of its existence. 87 albums were realized with over 50,000 copies, 2 clips and one book [megazin. megatotal.pl 2018].

The second crowdfunding platform specialized in cultural projects is wspieramkulture.pl (meaning "support culture"). This platform was established in 2012 and reached more than PLN 2,000,000 by September 2018.

233 successful campaigns realized since 2012 have been analyzed. They were divided into 14 categories: design, photography, architecture, film, theatre, music, dance, fashion, new media, handicraft, arts, publishing, comics and special projects. Projects offered on the platform usually feature in several categories in order to reach the largest possible groups of potential backers (e.g. "film" can be also "dance" or "music").

The results of realized projects analysis is similar to the one made by the European Commission. Most of the projects realized on the platform are theatre, music and film $(60.17 \%$ share by number and $74.44 \%$ share by value - see table 6$)$. The smallest number of donors are attracted to the categories of handicraft and comics.

Table 6. Share of the different categories in the total value and number of campaigns at wspieramkulture.pl

\begin{tabular}{|l|c|c|}
\hline \multicolumn{1}{|c|}{ Category } & Percentage share by value & Percentage share by number \\
\hline theatre & $32,07 \%$ & $14,29 \%$ \\
\hline music & $30,39 \%$ & $32,03 \%$ \\
\hline film & $11,98 \%$ & $13,85 \%$ \\
\hline publishing & $10,14 \%$ & $16,45 \%$ \\
\hline arts & $4,73 \%$ & $4,33 \%$ \\
\hline photography & $3,63 \%$ & $5,19 \%$ \\
\hline architecture & $2,04 \%$ & $2,60 \%$ \\
\hline dance & $1,38 \%$ & $4,76 \%$ \\
\hline fashion & $1,13 \%$ & $0,87 \%$ \\
\hline
\end{tabular}




\begin{tabular}{|l|c|c|}
\hline \multicolumn{1}{|c|}{ Category } & Percentage share by value & Percentage share by number \\
\hline design & $0,84 \%$ & $1,73 \%$ \\
\hline new media & $0,83 \%$ & $2,16 \%$ \\
\hline special projects & $0,71 \%$ & $0,87 \%$ \\
\hline handicraft & $0,08 \%$ & $0,43 \%$ \\
\hline comics & $0,05 \%$ & $0,43 \%$ \\
\hline Total & $100 \%$ & $100 \%$ \\
\hline
\end{tabular}

Source: own elaboration based on wspieramkulture.pl.

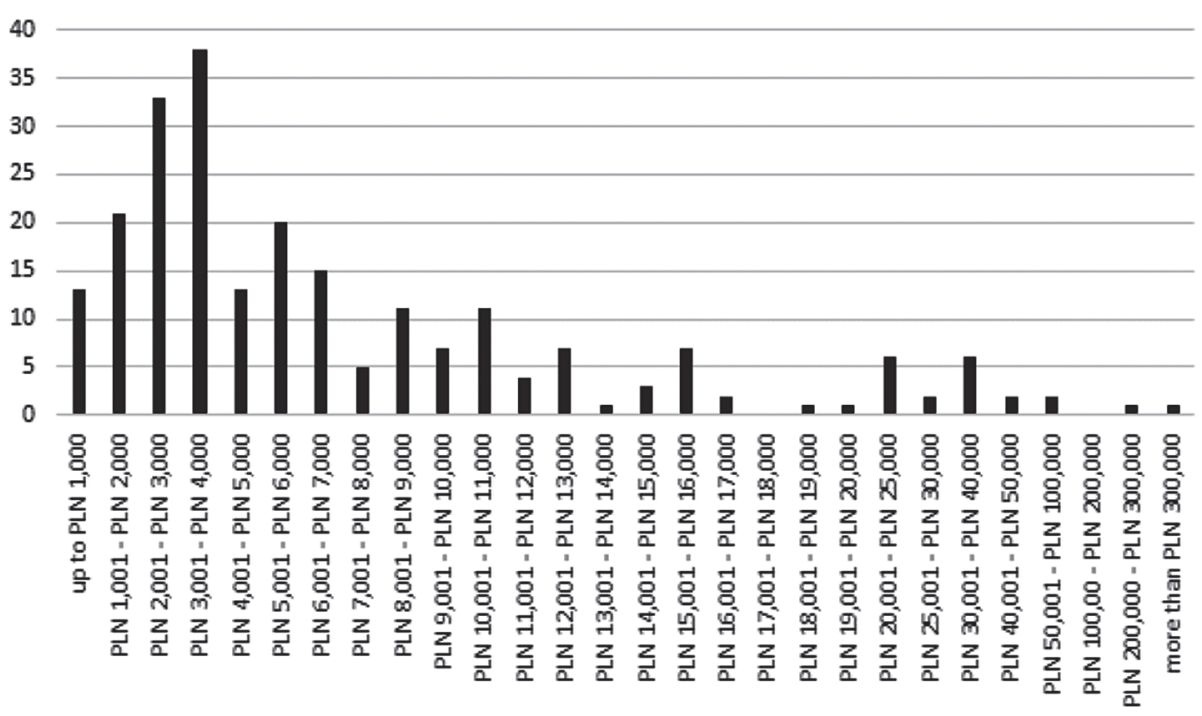

Picture 2. Number and volume of projects realized on wspieramkulture.pl (for the end of March 2018)

Source: own elaboration based on wspieramkulture.pl.

The value of projects that have been implemented on the platform since 2012 is very diverse, however, projects that do not exceed PLN 10,000 are dominant (see picture 2). They constitute over $75 \%$ of all completed projects. The most popular are initiatives worth from PLN 3,000 to PLN 4,000, with 38 successful collections. There were only six projects that reached more than PLN 40,000:

- „Become a Minister of Culture - support the Malta Festival” - project worth over PLN 307,000. The important fact is that the project was submitted after the subsidy by the Ministry of Culture and National Heritage was suspended. 
- "Protect Dialog, stop censorship" - project worth over PLN 200,000 for organization of International Theater Festival Dialog. This initiative was also suspended by the Ministry of Culture and National Heritage.

- Marriage 2017. Become the Patron of the Premiere in the $6^{\text {th }}$ Floor Theater project worth almost PLN 64,000.

- Weiss Wideo Orchersta - music project worth PLN 50,125.

- Co-opera - combination of classical and popular music, opera singing, poetry and light music, a fusion of modernity and classics, the project worth PLN 49,677.

- SIDE ONE TEN - album for the 10th anniversary of the iconic vinyl store, the project worth more than PLN 41,000.

This platform supports reward-based crowdfunding. It means that creators have to prepare some gifts which are rewards for donors. There are four main types of gifts: copies of the final work (e.g. book, CD, game), cooperation in the project creation (e.g. become a namesake of the hero in a book or game), presence in the creative process (e.g. visiting the recording studio, private concert) and creator's souvenir (e.g. photo with an autograph, personal greetings from the stage). Those gifts do not cost much but are important for people who identify with the project.

There are other crowdfunding platforms (general purpose platforms) where cultural initiatives are undertaken. The platform polakpotrafi.pl was created in 2011. It is the biggest crowdfunding platform on the Polish scene. This platform is not dedicated directly to cultural projects but campaigns for films, computer games, comics, music, art, theatre, dance or modern technologies can be promoted there. The funds collected on the platform since 2011 exceeded PLN 22,448,116 launching 3,674 projects [polakpotrafi.pl 2018].

The largest projects realized there are devoted to culture:

- Ribbon of Memory - a modern monument dedicated to the Polish Home Army at the foot of the Wawel Castle. This project started in February 2016 and was the result of the City Authorities' refusal to finance it from public funds. The initiators wanted to gather PLN 300,000. The goal was reached within two months, the total sum gathered was PLN 385,615 and it was the largest crowdfunding collection on the Polish market.

- Secret Service - reviving the computer magazine popular in the 90s. The goal was to reach PLN 93,000, the final sum was PLN 284,110.

- KOSMOS (Space) - the groundbreaking magazine for girls aged 7-11. The project was announced in 2017 and exceeded the goal (PLN 93,712) gathering PLN 131,269.

- Yellowbook project - the goal of this project, announced in 2016, was to publishing a book dealing with issues related to programming and design. The aim was to get PLN 26,000 and the final collection was PLN 102,741. 
- We are building school in Nepal - the project of rebuilding a school in Nepal destroyed after the earthquake. The Project was announced in 2015 and reached the goal of PLN 102,172.

Those examples show that societies are interested in supporting cultural projects in various forms. The wisdom of the crowd is more and more visible not only in the field of cultural but also social issues. Enterprises, organizations, foundations but also societies have an increasing social and cultural awareness. Although, for the time being, these are not large amounts, however, there is a growing interest in supporting such initiatives.

It should be emphasised that many of the projects do not receive funding or the funds do not reach the minimum goal. Statistics in this area are not accurate because unsuccessful project disappear from the crowdfunding platforms very quickly. On the other hand, it is worth remembering that even the failure in the first attempt creates added value. It teaches how to present and promote the initiative to be successful in the next installment.

\section{Conclusions}

The cultural sector faces difficulties in accessing traditional finance. Culture needs funds and societies can become its patrons. Crowdfunding offers an opportunity to obtain money from the crowd. It can be a chance for cultural initiatives which would otherwise not come into existence.

Examples from France and Italy show that the public is interested in supporting culture. The people want to be patrons of culture. Thanks to the co-financing of various projects, they feel that they are responsible for it. Foreign projects amount to incomparably larger sums than those implemented in Poland.

However, despite the fact that crowdfudning in Poland is just developing, Poles have been actively and willingly involved in financing culture through online gathering. "Ribbon of Memory" and "Weiss Video Orchestra" projects are examples of initiatives that would not have had a chance of existing without crowdfunding. The projects "Become a Minister of Culture - support the Malta Festival" or "Protect Dialog, stop censorship" are examples of crowdwisdom. These projects did not receive state funding, so citizens decided to co-finance them so that they could take place.

Crowdfunding and using crowd wisdom in financing cultural projects can be a beneficial and innovative tool but there are still many barriers. One of them is the uncertainty about the final cost-benefit result. The success of a campaign consists in the professional preparation and promotion. Cultural organizations do not want to waste time and money on something that will not work and crowdfunding requires some upfront investments without the certainty of the implementation. On 
the other hand, they must be aware that even an unsuccessful campaign will give them the knowledge and experience they will be able to use in subsequent initiatives.

The uncertainty about the fiscal treatment of funds and lack of tax incentives in many of the EU countries does not encourage to use this tool either.

Apart from this, the majority of crowdfunding platforms functioning on small local markets are faced with bottlenecks that prevent them from developing an international business.

The value of funds that are transferred to the culture through crowdfunding is systematically growing in almost all EU countries but it is still low. This is because the cultural sector has been supported by public funds in Europe. There is more potential of traditional financing than of crowdfunding. It has to be understood that crowdfunding can also become a ticket to traditional financing in the future. Successful crowdfunding campaigns should be recognized as a market signal about the creditworthiness for investors and traditional lenders. It is justified to broaden the research on crowdfunding in culture by analyzing the success factors of crowdfunding initiatives in further work.

Considering the insufficient funds allocated to culture (not only in Poland but also in the whole EU countries) crowdfunding may be the best way to provide financing to cultural units. Polish cultural centers, like in France and Italy, should consider using crowdwisdom to obtain funds.

\section{Bibliogiraphy}

Barański R. (2015), Finansowanie działalności kulturalnej, Warszawa: Beck.

Baumgardner T., Neufeld C., Huang P., Sondhi T., Carlos F., Talha M.A. (2015), Crowdfunding as a Fast-Expanding Market for the Creation of Capital and Shared Value, p. 115-126, www. wileyonlinelibrary.com [access: 23.08.2018].

Belleflamme P., Lambert T., Schwienbacher A. (2013), Crowdfunding: Tapping the Right Crowd, "Journal of Business Venturing", no. 29(5), p. 585-609.

Borowiecki R. (2004), Perspektywy rozwoju sektora kultury w Polsce, Warszawa: Oficyna Wydawnicza, p. 15-27.

Borowiecki R. (2005), System regulacji w kulturze - finansowanie, zarządzanie, współdziałanie, Kraków: Oficyna Wydawnicza Abrys.

Brüntje, D., Gajda O. (2016), Crowdfunding in Europe, London: Springer.

Chochorowska A. et al. (2016), Finanse kultury w latach 2007-2015, „Studia i Analizy Statystyczne", https://stat.gov.pl/files/gfx/portalinformacyjny/pl/defaultaktualnosci/5493/7/1/1/ finanse_kultury_w_latach_2007_2015.pdf [access: 28.09.2018].

Cunningham W.M. (2012), The JOBs Act. Crowdfunding for Small Businesses and Startups. New York: Apres.

De Voldere I., Zeqo K. (2017), Crowdfunding - Reshaping the Crowd's Engagement in Culture, Luxembourg: Publications Office of the European Union. 
Dresner S. (2014), Crowdfunding. A Guide to Raising Capital on the Internet, New Jersey: John Wiley\&Son, p. 18-87.

European Commission (2018), https://ec.europa.eu/digital-single-market/en/news/eu-budgetreinforcing-europes-cultural-and-creative-sectors [access: 30.09.2018].

Financing the Arts and Culture in the European Union (2006), http://www.europarl.europa.eu/thinktank/en/document.html?reference=IPOL-CULT_ET\%282006\%29375309 [access: 16.07.2018].

Flew T. (2017), Cultural and Creative Industries, http://www.oxfordbibliographies.com/view/ document/obo-9780199756841/obo-9780199756841-0188.xml [access: 27.09.2017].

Gałuszka P., Bystrov V. (2013), Platforma finansowania społecznościowego jako nowy typ przedsiębiorstwa na rynku kultury, „Studia i Prace Kolegium Zarządzania i Finansów SGH”, p. 124-162.

Gałuszka P., Bystrov V. (2012), Społecznościowe finansowanie produkcji dóbr kultury na przykładzie serwisu megatotal.pl, „Zarządzanie w Kulturze”, vol. 13, no. 4, p. 329-339.

Głowacki J., Hausner J., Jakóbik K., Markiel K., Mituś A., Żabiński M. (2008), Finansowanie kultury i zarządzanie instytucjami kultury, Kraków: Uniwersytet Ekonomiczny w Krakowie Małopolska Szkoła Administracji Publicznej, p. 2-124.

Harris J. (1986), A Statue for America: The First 100 Years of the Statue of Liberty, New York: Simon\&Schuster.

Ilczuk D. (2012), Ekonomika kultury, Warszawa: Wydawnictwo Naukowe PWN.

Ilczuk D., Misiąg W. (2003), Finansowanie i organizacja kultury w gospodarce rynkowej, Warszawa-Gdańsk: Instytut Badań nad Gospodarką Rynkową, p. 10-190.

Ingram C., Teigland R., Vaast E. (2014), Solving the Puzzle of Crowdfunding: Where Technology Affordances and Institutional Entrepreneurship Collide, "System Sciences (HICSS)", p. $4556-4567$.

Kappel T. (2009), Ex Ante Crowdfunding and the Recording Industry: A Model for the US, "Loyola of Los Angeles Entertainment Law Review", p. 375-385.

Kędzierska-Szczepaniak A., Szopik-Depczyńska K., Łazorko K. (2016), Innowacje w organizacjach, Warszawa: Texter, p. 69-104.

Kędzierska-Szczepaniak A., Próchniak J. (2018), Financing of Cultural Projects through Crowdfunding Platforms in Poland using the Example of wspieramkulture.pl, "Management Sciences Nauki o Zarządzaniu”, p. 13-22.

Klamer A. (2005), Creatieve financiering van creativiteit, [in:] “Boekmancahier”, vol. 17, no. 62, p. 6-11.

Kowalska M. (2015), Crowdsourcing internetowy. Pozytywny wymiar partycypacji społecznej, Warszawa: Wydawnictwo SPB Nauka-Dydaktyka-Praca.

Manda C.C., Nicolescu C.E., Mortelmans D. (2017), Financing Culture Institutions in European Context, http://www.europarl.europa.eu/thinktank/en/document.html?reference=IPOLCULT_ET\%282006\%29375309 [access: 27.09.2018].

Nocoń A. (2016), Źródła finansowania jednostek kultury, „Studia Ekonomiczne. Zeszyty Naukowe Uniwersytetu Ekonomicznego w Katowicach", nr 256, p. 7-19. 
Pluszyńska A., Szopa A. (2018), Crowdfunding w Polsce, Kraków: Wydawnictwo Uniwersytetu Jagiellońskiego.

Polzin F., Toxopeus H., Stam E. (2018), The Wisdom of the Crowd in Funding: Information Heterogeneity and Social Networks of Crowdfunders, "Small Business Economics", vol. 50 (2), p. 251-273.

Prpić J., Shukla P.P., Kietzmann J.H., McCarthy I.P. (2015), How to Work a Crowd: Developing Crowd Capital through Crowdsourcing, "Business Horizons", vol. 58, p. 77-85.

Ridge M. (2014), Crowdsourcing Our Cultural Heritage, Burlington: Ashgate Publishing Limited, . Stano-Strzałkowska S. (2017), Finansowanie kultury ze środków publicznych, przykłady krajów europejskich, Ogólnopolska Konferencja Kultury, http://konferencjakultury.pl/_admin/ stuff/okk_finansowanie_kultury_1.pdf [access: 28.09.2018].

Statistical Book Eurostat (2016), Culture Statistics, Luxembourg: Publications Office of the European Union.

Surowiecki J. (2004), The Wisdom of Crowds: Why the Many are Smarter Than the Few and how Collective Wisdom Shapes Business, Economies, Societies, and Nations, New York: Doubleday. Świerczyńska-Kaczor U., Kossecki P. (2016), The Role of Polish Crowdfunding Platforms in Film Productions - an Exploratory Study, Federated Conference on Computer Science and Information Systems, Gdańsk.

Tomczak A., Brem A. (2013), A Conceptualized Investment Model of Crowdfunding, "Venture Capital", vol. 15, issue 4, p. 335-359.

Ustawa z dnia 25 października 1991 o organizowaniu i prowadzeniu działalności kulturalnej, Dz.U. 2001 Nr 13, poz.123 z późn. zm., wspieramkulture.pl [access: 11.09.2018].

www.tousmecenes.fr https://www.tousmecenes.fr/en/modules/owners-of-the-book-of-hours. 13.09.2018 [access: 13.09.2018].

www.megazin.megatotal.pl [access: 28.03.2018].

www.mofnet.gov.pl [access: 9.09.2018].

https://polakpotrafi.pl/projekt/pomnik [access: 5.05.2018].

http://presse.louvre.fr/become-a-patronof-king-francois-is-book-of-hours/ [access: 25.09.2018]. http://lventuregroup.com/loveitaly-crowdfunding-for-the-italian-cultural-heritage/?lang=en [access: 12.09.2018].

http://www.nina.gov.pl [access: 20.05.2018].

http://www.mkidn.gov.pl [access: 20.08.2018].

https://artbonus.gov.it/english-brief.html [access: 12.09.2018].

https://polakpotrafi.pl [access: 15.09.2018].

https://www.kickstarter.com [access: 30.09.2018]. 